\title{
Narativní koherence jako průvodní rys proměn žánru. Na příkladu próz s historickou tematikou
}

Alice Jedličková

\begin{abstract}
Narrative coherence as an accompanying feature of genre evolution. Exemplified by historical fiction

The paper results from a project that inquires into narrative modes in Czech 19th century fiction. Drawing on findings in the genre of historical fiction (by F. A. Rokos, P. Chocholoušek and Karel Sabina) it poses the question whether at all, and to what extent narrative coherence may be taken into account in literary communication of the period and whether it may be considered a marker of evolution of the genre. This inquiry is conditioned by a differentiation between narrative and textual coherence, since the former seems to have a broader meaning, while the latter has been conceptualized as a result of analyzing mainly contemporary pragmatic texts. The second precondition is to eliminate the risk of applying the notion of coherence retrospectively. Both categories are put on test in relating them to other medial narratives, and individual historical features of (in)coherence are compared with alternative narrative options of the time.
\end{abstract}

\section{KEYWORDS}

Textual coherence; narrative coherence; AI; storyworld; narrative discourse; Czech 19th century fiction.

\section{KLÍčovÁ SLOVA}

Textová koherence; narativní koherence; umělá inteligence; narativní diskurz; česká próza 19. století. 
Mezi charakteristikami modernistického narativu se vedle epistemického znejistění často objevuje rozrušení tradiční narativní struktury a koherence. Většinou však není řečeno, že to, co je obsahem oné tradiční (tj. nějaké historicky ustálené kvality udržující) struktury, je spíše nadčasový narativní prototyp. Ten se vyznačuje tím, že události spojené s přehlednou konstelací jednajících sil jsou v něm řazeny v zásadě chronologicko-kauzálně a souvisle vyprávěny. Pokud si pod tradiční narativní strukturou máme představit poetologickou abstrakci z určité množiny skutečných literárních děl, jimž přisuzujeme povahu významově uzavřeného komplexního narativního zobrazení, jako jsou realistické venkovské či společenské romány, pak při konkretizaci této představy českou prózou nezbývá než konstatovat, že „rozrušování tradiční struktury“ v ní nastává v situaci, kdy se jí domácí literatura konečně s jistotou dobrala.

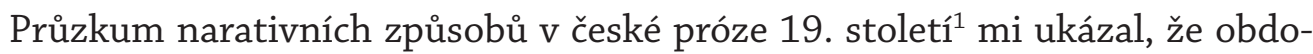
bí, v němž česká próza vyhovuje představě ucelenosti a koherence, je vlastně dost krátké. Rozhodně mnohem kratší než období, v němž se vyznačuje alespoň některými z těchto rysů: děj tvoří události vágně propojené nelogickými obraty v jednání postav a náhodami; žánrově typické postupy sice slouží jednomu příběhu, vyprávění však dělí na samostatné textové segmenty, jejichž obsahy na sebe navazují spíše tematicky než v časové a příčinné souvislosti; vyprávění je opakovaně přerušováno retrospektivami, jejichž úkolem není přivést čtenáře k rozpoznání motivací postav, nýbrž důkladně ho poučit o zvyklostech dané doby a prostředí; retrospektivní podání ilustrativních událostí a ještě více iterativní vyprávění o tom, jak to „chodívalo“ přitom často konkurují podání vlastního děje příběhu; vyprávění je nahrazeno ukázkou z dobového pramene, který ovšem danou událost podává z odlišné perspektivy a jinou dikcí, než je ta vypravěčova. Tyto vlastnosti nejsou náhodnými příklady, některé vycházejí z individuálních textů, jimž se ještě budeme věnovat, jiné patří k příznačným vlastnostem narativů s historickou tematikou v první polovině století, jež v té druhé ještě dlouho přetrvávají. Dosažení oné „tradiční“ sevřené struktury, tj. př́iběhu odhalujícího logiku děje skrze vyvážený poměr postav a událostí v koherentním vyprávění, zůstává v české próze 19. století nadlouho vzdálenou a vlastně nijak zvlášt atraktivní metou. $\mathrm{V}$ diskusích s kolegy zkoumajícími literaturu raného novověku se obnažily hluboké kořeny tohoto stavu.

Přestože se koncem 18. století zřetelněji diferencuje historiografie a narativní fikce s minulostní tematikou, udržuje se mezi nimi nadále „obousměrný pro-

1) GA ČR 18-04420S, Proměny narativních způsobů v české próze I. Průběžně budu odkazovat i na poznatky kolegů z tohoto projektu. 
voz“, sdílení postojů a interpretací. ${ }^{2}$ Některé rysy a funkce vyprávění s historickou tematikou se jeví dokonce jako přetrvávání jeho vlastností z předcházejících období: konstatuje-li Jan Malura, že (od konce 16. století narůstající) literární tvorba reflektující minulost představuje důležitou složku celého kulturního systému, která plní vzdělavatelnou funkci ve vztahu k různým oblastem (politické, náboženské, srov. MALURA 2021: 157), pak lze říci, že takové postavení si historické fikční psaní uchovává i v 19. století. A přetrvává v něm dlouho i princip práce s pretexty, často autoritativními, jež jsou vkládány do vlastního vyprávění - a to způsobem spíše více než méně nápadným. Rozhodně platí, že spisovatelé neváhají sáhnout občas spíše „k nůžkám než k peru“, použijeme-li Malurovu metaforu (tamtéž), byt' už se nejedná o kompilační psaní raně novověkých textů. Klade se tedy otázka, kde se berou ony ucelené koherentní narativní struktury, jež jsou v určitou chvíli umělecky rozrušovány? Anebo jinak: není vlastně retrospektivní aplikace pojmu koherence problematická?

Podíváme-li se na vývoj pojmu samého, musíme uznat, že to je otázka či námitka relevantní. Jak pojem narativní koherence $\mathrm{v}$ teorii vyprávění, tak pojem textové koherence v textové lingvistice jsou mnohem mladší než materiál, nad kterým uvažuji. Obě konceptualizace spadají do sedmdesátých let minulého století a obě jsou do jisté míry limitovány dominantním materiálem výzkumu. Teorii vyprávění zaostřené na narativní diskurz bylo ještě počátkem tisíciletí možno vyčítat, že preferuje nejen moderní, ale ještě více modernistický a postmoderní narativ. Textová lingvistika zase hodně pracovala s texty odbornými; nechci ted' tuto disciplínu redukovat na nějaký obecný návod k úspěšnému psaní textu, ale přece jen styl a žánry odborné jsou oblastí, kde je možné a nanejvýš užitečné nastavit podmínky, za nichž text optimálně plní svoji komunikační funkci. Koherencí se v textové lingvistice a stylistice rozumí významová soudržnost textových jednotek dosažená nejen určitým způsobem konstruování textu, ale také s využitím prostředků formální návaznosti textu (koheze; srov. ČECHOVÁ et al. 2008: 119-121). Funguje to ovšem i obráceně ve dvojím smyslu: Zaprvé je koherence $\mathrm{v}$ textové lingvistice parametrem textovosti - to ovšem u literárního psaní připouštějícího útržkovitost a fragmentárnost či vícepásmovou kompozici neplatí. Zadruhé koherence může být i výsledkem procesu recipientova rozumění komunikátu, v němž se uplatní situovanost komunikace, recipientovo povědomí o širších souvislostech komunikovaného tématu, jeho dřivější zkušenosti a vědění o světě jako kognitivní rámce. Recepční perspektiva sbližuje

2) Tomuto tématu se mj. věnuje Václav Smyčka v monografii Objevení dějin. Dějepisectví, fikce a historický čas na přelomu 18. a 19. století (2021). 
lingvistické pojetí koherence s narativním: koherence literárního textu vyvstává $\mathrm{v}$ procesu recepce nejen $\mathrm{z}$ jeho vlastností, ale také $\mathrm{z}$ kontextu, který kromě zkušenosti a „vědění o světě“ zahrnuje i „vědění o literatuře“, znalost žánrových konvencí a rozpoznání intertextových vazeb.

Potvrzení tohoto stanoviska najdeme v encyklopedickém hesle britského naratologa Michaela Toolana v Living Handbook of Narratology (2011, revize 2013); propracovanější teoretický přehled v kontextu teorie vyprávění zatím nemáme $\mathrm{k}$ dispozici. Toolan v úvodu svého výkladu připomíná, že v kulturní komunikaci obecně s sebou pojem koherence nese celý soubor pozitivních kvalit, jako jsou přehlednost, uspořádanost, jasnost výrazu, čitelnost, logika. Shrnuto: jako koherentní se jeví takový komunikát, který má, kolokviálně řečeno, „hlavu a patu“, který má zřejmý smysl. Patrně s tímto širším náhledem lze spojit Toolanovo stanovisko, že koherence je implikována už narativními gramatikami, jež identifikují základní konstelace postav, jejich vztahů a možných interakcí, z nichž vzniká příběh. Zdá se mi však, že komplexní kvalita, která je tu vpravdě implikována, je spíše logika příběhu, ostatně vystižená už v titulu jedné ze zakladatelských naratologických studií, v Bremondově Logice narativních možností (1966).

Logika ostatně určuje i další předpoklad narativní koherence, totiž zachování identity již identifikovaných postav. K téže postavě se sice může odkazovat různými opisnými způsoby: mladý muž, zamyšlený vysoký blondýn, Jan - ale od chvíle, kdy je postavě přiděleno jméno, počítáme s tím, že vysoký mladý muž s blond vlasy, který se jmenuje Jan, je stále táž osoba, postava příběhu, jeden z jeho existentů, jak je označuje Seymour Chatman (1978). Z pohledu textové lingvistiky se tato úvaha může jevit zbytná, smyslu nabude ve chvíli, kdy princip identity otestujeme na jiném médiu a dokonce ,jiném“ původci narativu.

První test vychází z univerzality př́iběhu a různosti mediálních prostředků, jimiž ho lze předvést: Budu-li coby osoba, která se v moderním tanci př́liš nevyzná, sledovat taneční choreografii sugerující svým názvem příběh, pak se v očekávání narativní struktury budu od počátku snažit rozlišit tanečníky jako postavy př́iběhu, možná jim i trochu naivně „přidělit“ role, abych mohla dále sledovat, jak si v nich počínají, jaké se mezi nimi vytvářejí vztahy a jaké mezi nimi vyvstávají konflikty. Konstituenty (existenty) světa příběhu představují právě jen oni, takže neutrální jevištní prostředí poskytující volný prostor mi žádná vodítka podporující koherenci př́iběhu a tedy i moje rozumění neposkytne; zachování identity postav ano. Bude-li se naopak identita postav měnit, budu tomu nejspíše rozumět tak, že nejde o konkrétní příběh, ale spíše o parabolu stavu světa, 
v němž nic není jistého. $\mathrm{K}$ druhému testu mi materiál poskytl kolega Richard Müller, jehož další úvahy tu čtenář najde ve studii psané společně s Matoušem Jaluškou. Vytvoření koherentního narativu totiž vyžaduje náročné intelektuální operace, a je proto vhodným ověřením úrovně umělé inteligence. $V$ případě doporučeném kolegou měla umělá inteligence vytvořit na základě osvojení obsáhlé databáze sci-fi filmů vlastní scénář. ${ }^{3}$ Umělá inteligence se sice naučila imitovat jeho formu, rozlišit scénické poznámky a dialog, problémem ale pro ni zůstala věcná koherence. A to především zmíněná chatmanovská kontinuita existentů, tedy identita postavy spojená se jménem, konzistence postavy a prostoru (postava byla např́iklad současně umístěna do dvou míst), i koherence komunikační: zatímco textovou kohezi jednotlivých výpovědí a tematickou koherenci replik umělá inteligence zvládla dobře, komunikace brzy ztrácela smysl.

Poznatek, který z toho můžeme vyvodit, je ten, že jedním z předpokladů narativní koherence ve smyslu uspořádanosti narativního diskurzu je konzistence světa príběhu. Teoretici fikce samozrejmě mohou namítnout, že fikční narativ může experimentálně představit i tzv. nemožný možný svět, který připouští logické rozpory. Historici starší literatury zase to, že $\mathrm{v}$ dílech utvářených na základě překladu a opakovaných přenosů a přepracování pretextu vícerými autory $\mathrm{k}$ tomu dochází prostě $\mathrm{v}$ důsledku tohoto transformačně-aditivního procesu. Formulujme to tedy takhle: nedodržení konzistence světa příběhu je jednou z možných překážek narativní koherence; stejně tak vyprávění, které sice může být informačně nasycené, ale neobsahuje dostatek vodítek k rozpoznání logiky vývoje událostí a ustavení smyslu příběhu. (Při této př́ležitosti se ukazuje, jak účelné je analytické dělení narativu na přiběh a narativní diskurz.) V rámci zkoumání diachronní narativní poetiky se hlavně nabízí zjistit, zda je koherence vůbec podstatná, a pokud ano, jaké jsou její konkrétní dobové prostředky a nakolik se podílí na realizaci komunikační funkce textu.

3) Filmař Oscar Sharp se spojil s odborníkem na digitální technologie a AI Rossem Goodwinem, aby vytvořil „stroj, který dokáže napsat scénář“. Vytvořili proto umělou inteligenci (pod jménem „Jetson“) pracující na bázi neuronové sítě, jež se dokáže učit a pamatovat si (tzv. deep learning). „Nakrmili“ sít velkým množstvím sci-fi filmů a seriálů, aby si osvojila jejich pravidla. Výsledný scénář pak zpracovali s herci v krátkém filmu Sunspring (2016). https://www. youtube.com/watch?v=LY7x2Ihqjmc\&ab_channel=ArsTechnica; 〈př́istup 29. 9. 2021〉. 


\section{Adice textových typů a tematicko-paradigmatická koherence}

Jako první příklad volíme povídku Zasnoubení na bojišti (1824) Františka Alexandra Rokose. Náleží k autorům, kteří reagovali na zásadní podnět Lindovy Záre nad pohanstvem (1818) „inscenujíci“ dávnou minulost; modelovost její strukturace se promítá i do Rokosovy povídky. Historickým zázemím příběhu je tu bitva mezi Soběslavem II. a knížetem Friedrichem roku 1178. Vlastním příběhem je však láska vzniklá ve válečném čase, pevný vztah potvrzený partnerstvím v boji a slavnostně zpečetěný tak, jak je vyznačeno v titulu. Protagonisty jsou mladičká osiřelá Kráska, vychovávaná pěstounem Ratiborem, a mladý bojovník Milovín. Ratibor s dívkou obřadně navštěvuje hrob, aniž by jí vysvětlil, koho oplakává. Tajemství jí zjeví právě na začátku vlastního děje: Krásčin otec, Ratiborův jediný syn Milvoj, se vydal do boje proti knížeti Bedřichovi (Friedrichovi); jeho těhotná žena ho nedokázala opustit. Krásku porodila uprostřed bojů a krutý Bedřich zabil nejen Milvoje, ale i rodičku. Když se dívka, zdánlivě křehká a v lesní samotě neuvyklá světu, dozví o př́ičině smrti rodičů, zatouží po pomstě. K tomu přispěje setkání s poslem knížete Soběslava, Milovínem: má pozvat Ratibora do vojska jako zkušeného velitele, a ten dojatě přijímá „svatou povinnost“ vuiči národu. Milovín se přitom zahledí do Krásky. Ta se poté pro lásku i pomstu tajně vydá do vojenského tábora přestrojena za mladého muže; spolubojovníkům se představí jako Krásoslav a Milovínovi dá znamení v písni, kterou všem přednese. Dvojice si přísahá věrnost a společně ochrání Soběslava v boji. Společně také oba přisypou svoji přilbici hlíny na hrob zaživa pohřbívaného saského vůdce Heriberta. ${ }^{4}$ Synopticky shrnut působí příběh spojený vyhraněnou konstelací postav uceleně. Rozpoznáváme v ní navíc oblíbené schéma historizující prózy, a sice křehkou a půvabnou mladou dívku coby schovanku starého otcovského opatrovatele (at' už otce, děda či pěstouna), často zkušeného válečníka, jehož úlohu ochránce převezme silný a spolehlivý mladík. ${ }^{5}$

4) Na tomto místě (jako již v odkazu na bitvu samu) zaštituje se Rokos autoritami Hájkovou a Pubitschkovou: shodly jsme se v interpretaci s Kateřinou Pioreckou, že v tomto případě se nám poznámka „Hájek a Pubička to vyprávěji“ (ROKOS 2005: 51) jeví jako vypravěčův pokus o „roznesení“ morální odpovědnosti za podání zprávy o tak drastickém činu velebených předků.

5) Podobně v Markově časově souběžné Růži na poušti (1825), ale i v Chocholouškových Templářích v Čechách (1843), či v Anežce Přemyslovně (1878) Beneše Třebízského. Konstrukce postav je založena na společné matrici vlastností, které se promítají do textových a situačních modulů, například rozpoznání (divadelně „zakuklené“) postavy či alespoň odhalení dívčího půvabu. Tak je tomu i v Rokosově příběhu, kde vítězný kníže vyzývá bojovníky, aby na znamení vítězství zasypali přilbou hlíny poraženého saského vojevůdce Heriberta: „Tato slova dopověděv, sňal sám naproti němu stojícímu Krasoslavovi stříbroskvělou přílbici z hlavy, a aj, - hebounkých kadeří proudové po jeho 
Kráska se navíc ukáže jako skrytá Amazonka, jíž patrně zrození ve válečné vřavě poskytlo dar bojového umění, $\mathrm{k}$ němuž nebyla cvičena, a přesto bez zábran pozvedne zbraň a zdatně si vede v boji. Svým štítem zastaví útok na samého Soběslava, Milovín poté vytrhne útočníka ze sedla a zachrání tak panovníka i svou spolubojovnici se štítem roztřištěným strašnou ranou. Všimněme si, jak je rodově symbolicky rozdělena záchrana knížete: bojovnice poskytne záštitu, bojovník likviduje nepř́itele.

Děj povídky (s tajemstvím, pomstou, „kuklením“ postavy, hrdinským činem a štastným svazkem milenců) je v zásadě jednoduchý. Vyprávění je ovšem složeno $\mathrm{z}$ textových segmentů různé délky a různého žánrově-formálního charakteru: dvě $z$ témat příběhu (bolestnou ztrátu a tlumenou touhu po pomstě) předznamenává krátká úvodní báseň či píseň. Atmosféru vyvolanou usazením Soběslava na knížecím stolci líčí textový modus, který bychom spíše než za vyprávění označili za popis kolektivního jednání a chování, který má svědčit o jednotě a oddanosti panovníkovi: „ozvalyt' se mužné hlasy“, „udatní jinochové [...] ostřili sobě tupé meče“, „vprýštilat' se do prsou jejich hluboko slova dědů“ apod. (ROKOS 2005: 24 a 25). Následuje iterativní vyprávění o pravidelných Ratiborových a Krásčiných návštěvách u hrobu. Do jedné z nich vpadá se svým poselstvím Milovín. Jeho komunikace se zprvu nedůvěřivým Ratiborem je předvedena formou dramatického dialogu ${ }^{6}$, to znamená, že uvozovací věty jsou nahrazeny často jen jmény mluvčích, resp. krátkými „scénickými poznámkami“.7 Ratibor uzavře svůj příslib služby knížeti obřadným generalizujícím opisem: „Ranním jitrem jsem ve vašem sboru; jdi vyřídit mé odpovědi národu“ (IBID.: 28, zvýr. AJ). Neméně vznosnou dikcí vypravěče pokračuje vložené Ratiborovo vyprávění o neblahém osudu Krásčiných rodičů a vysvětluje, že pomsta odložená do času ohrožení týmž nepřítelem je spravedlivější. Tuto část vyprávění tematicky uzavírá druhá strofa úvodní písně. Formou dramatického dialogu je podáno obřadné Ratiborovo přijetí u Soběslava i zdánlivě náhodné setkání Milovína s neznámým mládencem Krasoslavem, totiž „zakuklenou“ Kráskou. Ta dobře zapadne mezi ostatní mladé bojovníky a slíbí jim zpěv k povyražení: je to epická píseň rekapitulující osud jejích rodičů a současně vyznání pochybujícímu Milovínovi.

brni se rozplynuli. Překvapený jsa kníže, pustí přílbici na zem a bystře hledí na - růžolící dívku, ana stydlivě na zem krásné oči upírá" (ROKOS 2005: 52).

6) V jmenovaném projektu se Kateřina Piorecká zabývá dramatickým dialogem jako jedním z hlavních způsobů zprostředkování narativních informací právě v historizující próze první poloviny 19. století; takové užití totiž mění rozsah moderních pojmů čas vyprávěný a čas vyprávění (a tedy představu narativní temporality) a vztah shrnující vypravěčské zprávy a dialogické scény.

7) „Ratibor (př́isným okem na Krásku pohledna): Neobměkčuj mne svou upěnlivou vždy prosbou. (k vojínovi) Potřebuje vlast mé rámě?"“ (ROKOS 2005: 27). 
Přednašečka poté zmizí; když se znovu setkají před bojem, je jejich tiché vyznání, opět podané dramatickým dialogem, zakukleno jako slib bratrství v boji, pečetěného vlastenectvím („Krasloslav: ,Víš snad, když Čech ruku podá, že slovo také drží“, IBID.: 46). Bitva je líčena jazykem básnických epitet a amplifikujících metafor, zpráva o průběhu události je zastíněna sugestivními obrazy. ${ }^{8}$ Závěr tvoří „citace“ písně zaznívající na oslavu vítězství a rekovných Čechů.

Různorodost textových segmentů překlenují dva faktory: Zaprvé to, že jednotlivé slohové útvary či formy reprezentace dávné minulosti jsou už ověřené a potvrzené Lindovou Září nad pohanstvem, jež nabývá povahy textového prototypu zahrnujícího lyrickou i epickou píseň, sugestivní obrazný popis atmosféry, zvyklostí a jednání postavy, dialogické předvedení situace namísto zprávy o události. Další zdrojem narativní koherence je nastavení světa př́běhu, propojení tematických prvků, které v dobové kultuře vytvářejí určité paradigma dávné hrdinské minulosti, a vytvářejí tak matrici pro její oslavu skrze konkrétní příběh. Je to již zmiňovaná konstelace postav (vládce jako ochránce češství, moudrý starý bojovník, mladičká „Amazonka“, silný a věrný mladík); pomsta vykonaná potomkem na vojsku původce rodinné tragédie; nový svazek slibující pokračování rodu chrabrých Čechů; vojenský střet s historickým pozadím. ${ }^{9}$ Tento soubor tematických a hodnotových parametrů světa příběhu zaručuje koherenci, kterou bychom mohli označit koherenci tematicko-paradigmatickou.

\section{„Nastavované“ vyprávění}

Termín „nastavování“ pochází také ze společné práce na projektu a vypůjčila jsem si ho od Jiřího Kotena: ${ }^{10}$ právě v historizující próze jím souhrnně označujeme takovou práci s dalšími diskurzy a př́islušnými textovými typy, která sice přidává další informace, jejich funkce je však hlavně naučná a přesvědčovací, a spíše než k rozvíjení děje tak přispívají k rozšíření narativního diskurzu.

8) Také klíčová akce děje, totiž rychlá záchrana Soběslava mladým párem, je prostoupena obrazy: „Co střela letí napřed pod rozhněvaným Soběslavem rychlonohý broň, sotva země se dotýkaje, a jako hrom do tvrdé skláy udeřiv, pod patu jeji se sveze: tak jeho jarobůjný broň, vraziv do ocelem ozbrojeného vraníka, omráčený hlavou k zemi klesá. Mžitkoletá rána břitkého meče, jenž Soběslavovi zhasnout měla svíci života, roztřiští nasazený štít hbitého Krasoslava [...] atd.“ (ROKOS 2005: 48).

9) Kateřina Piorecká upozorňuje na selektivitu prózy ve vztahu k historickým faktům: „O několik dní později byl totiž ,selský kníže‘ Soběslav II. poražen právoplatným dědicem Bedřichem za podpory moravského markraběte Konráda II.“ (cit. z rukopisu). Dílčí závěry z tohoto výzkumu in PIORECKÁ 2020.

10) Zavádí jej v již jmenovaném projektu ve studii věnované autoritě vypravěče. Problém „nastavování“ ostatně znesnadňuje i žánrovou klasifikaci Chocholouškových často velmi obsáhlých próz. 
Pro ilustraci tohoto jevu a jeho důsledků pro narativní koherenci jsem vybrala Chocholouškovu prózu Hrad (1860).

Už na začátku bylo konstatováno, že kamenem úrazu zkoumání koherence může být sklon přenášet současné nároky na dobový materiál. $V$ tomto případě připouštím, že moje pozorování koherence je ovlivněno blízkým, ale přece jen odlišným parametrem ideové konzistence. Podnětem je motto, jímž autor uvádí vyprávění příběhu z posledních roků třicetileté války: „,Ve hloubi duše žal ho svírá, / a přec v něm zpurná tužba neumírá. 'Mazeppa' od Puškina“ (CHOCHOLOUŠEK 1900: 3). Zajímavé na této citaci je už to, že pod uvedeným titulem odkazujícím k eponymnímu hrdinovi vyšla epická báseň Byronova, a to v roce 1819, tedy o deset let dříve než Puškinova skladba vydaná s titulem Poltava (1829). Zatímco obsah citátu zdưrazňuje propojení bolesti s přetrvávajícím vzdorem, a spíše než zdrojem konkrétních významů je výrazem intenzity prožitku jednotlivce, stávajíc se tak gestem nanejvýš romantickým, jeho atribuce odkazující k protagonistovi Puškinova příběhu v sobě nese konotace historické. Podobně jako postavy Chocholouškovy povídky se ukrajinský hejtman (a to v historickém čase o více než padesát let později) spojil se švédským vojskem proti panovníkovi (Petru I.), ovšem ve sporu nezakrytě politicko-geografickém, byt' i v něm se sešli zástupci jiného vyznání. Individualistické vyznění motta spolu s Mazepovým jménem může čtenář chápat jako určitý návod ke čtení, jako gesto, které si má spojit s výraznou postavou. Jenže se kterou? Následující příběh totiž jasného protagonistu-individualistu nemá. Nápovědou by ovšem mohla být hned první epizoda z prehistorie př́iběhu, jež má obrazný charakter a funkci: malý Kašpar Kaplíř ze Sulevic, vnuk popraveného téhož jména, nechává z utaté dědovy hlavy padnout krvavou krůpěj na svou hlavu: od té chvíle a po celý život pak toto „stvrzení pokrevenstvi“" vnímá jako závazek k pomstě. Mohli bychom se tedy domýšlet, že on je tím, jehož duši svírá neustávající žal.

Začátek vyprávění v modu barvitého historického obrazu ${ }^{11}$ - žoldnéřủ a pobudů rvoucích se o majetek vydrancovaný v domech „kacířü“ - připomíná atmosféru po popravě českých pánů 21. června 1621; následuje výše uvedená krátká epizoda s krví stvrzeným závazkem. Vlastní příběh se počíná v zimě 1645 představením jezdců v krajině: tři bratři Kaplířové, již jmenovaný nositel pomsty Kašpar, veselý voják Zdeněk a nejmladší, jemný, ale v postojích pevný Oldřich,

11) Princip obrazu stvrzuje Chocholoušek také gestem zvoucím čtenáře jakoby k přímému nahlédnutí situace: „Byla to pravá strakatina, ten lid, jejž tu spatřujeme; žoldnéři, lid otrhaný, ano mnohdy se objevila postava v obleku měštáanském“ (CHOCHOLOUŠEK 1900: 3, kurz. AJ). Vidíme tu neutrální epické préteritum a vedle něj prézens, který zpř́ítomňuje scénu a zároveň angažuje čtenáře. 
a jejich strýc Pavel Osterský Kaplír ze Sulevic se vracejí ze Saska na rodové sídlo, hrad ve Voticích. Ten získal Sezima z Vrtby za služby císaři; jeho ženou je Barbora, rozená Martinicová, hrdá necitelná krasavice, jež logicky chová k protestantům i osobní nenávist. Setkání politických a náboženských protivníků se Kaplířové nejdřive snaží překlenout lstivým přihlášením k jinému rodu, odhale(1) ni však zůstanou proti Vrtbům stát i jako odpůrci v majetkovém sporu. Přesto mezi Oldřichem Kaplířem a mladičkou dcerou hraběnky z Vrtby vznikne náznak milostného vztahu. Zkušený Pavel Osterský chce nejprve postupovat politicky a navrhne jako řešení sňatek mladých lidí. Hraběnka z Vrtby pyšně odmítne a zbožná dívka sama to má za nemožné pro rozdíl ve vyznání. Kašpar prosadí návrh, aby hraběnku s dětmi Kaplířové vzali jako rukojmí do Saska a od Sezimy pak požadovali jako výkupné navrácení rodového pokladu, jehož přítomnost mu prozradil nevěrný hradní správce. Oldřich však hraběnku s rodinou z votického zámku tajně propustí, aby se nestala předmětem pomsty jako kdysi jeho rodina vlastní. Vede jej $\mathrm{k}$ tomu nejen náklonnost $\mathrm{k}$ hraběnčině dceři, ale také nesouhlas s Kašparovým záměrem. Strýc Pavel se nejdřív zlobí, ale pak souhlasí $s$ tím, že není na místě napodobovat nenávist nepřátel, a Oldřichovi odpustí. V brzy následující bitvě u Jankova, v níž švédské vojsko fatálně porazí císařské, Pavel Osterský umírá a loučí se s nadějí, že už nebude třeba bojovat proti vlastním a že jeho synovci budou mít domov. Nad Voticemi pak zavlaje prapor Kaplír̆ů spolu s černým.

Vidíme, že jedním z očividně sjednocujících formálně sémantických prvků je „znamení na začátku a na konci vyprávění, v prehistorii a závěru příběhu. Vidíme ale také, že úvodní individualistické gesto (vztahovalo-li se opravdu k postavě Kašpara) vyznělo vlastně naprázdno. Příběh totiž ukázal další možnosti řešení konfliktu: politické jednání, gesto čiré lidskosti či smíření, zastoupené ostatními postavami. Uzlové body rozhodování a konání jsou tak rozděleny mezi jednotlivé př́islušníky rodu.

Děj je vystavěn na základně dvou spolehlivých, čtenářsky atraktivních dějových schémat: „láska s překážkami“ a „pomsta potomka za drahé“. Zjednodušeně řečeno přitom konkrétní realizace prvního schématu (Oldřichova láska se nenaplní, ale pomůže mu překonat překážku odlišného vyznání a zájmů) ruší možnost uskutečnění druhé, totiž Kašparovo dokonání msty. Přispívá k tomu právě konstelace postav. Ty jsou sice zobrazeny také na základě ověřeného schématu (zevnějšek, zvláště fyziognomie hrdinů je velmi tradičně prvoplánovým obrazem povahy, stejně tak bezděčné projevy chování tří povahově zcela odlišných bratři Kaplířù), ale jejich úlohy v ději mechanicky přiděleny nejsou. Postoj 
nejstaršího z bratří, věčně zachmuřeného a vznětlivého Kašpara, je výrazem nesmiřitelného odporu ke katolíkům a vášnivou touhou po odplatě. Prostřední Zdeněk je typem vojáka, který si z ničeho nedělá hlavu, a emocionálně nejvyšší hodnotou je pro něj bratrství ve zbrani, jak se potvrdí v závěru vyprávění. Nejmladší Oldřich tu jako nositel lásky mezi příslušníky dvou znepřátelených rodů nezastupuje jen emoce, ale jak už víme, také humanistické smýšlení. Jejich strýc Osterský je politik, jemuž jde o nábožensko- a majetkoprávní narovnání. ${ }^{12}$

Takto rozložen - tj. hlavně mezi silné mužské zástupce protestanské strany mohl zůstat nosnou linií příběhu střet touhy po pomstě a lásky nerozdmychávající vášně, nýbrž probouzející empatii a vedoucí nakonec k smíření. Kdyby se byl Chocholoušek ve vyprávění přidržel pouze jednání těchto postav jako nositelů určitých postojů, mohl vzniknout poměrně atraktivní napínavý příběh zachovávající současně to, čemu se říká „historické jádro“, tj. náboženské a mocenské přičiny konfliktu, nezakrývající negativa na straně protestantů a dovolující přitom jejich morální vítězství.

Vyprávění příběhu, který jsme tu načrtli, je doplněno způsobem, který bychom mohli označit právě za „nastavování“. Jak už bylo řečeno, expozice má charakter názorného historického obrazu: minulá událost se čtenáři „staví před oči“ a autentifikační strategií je tu ztotožnění jejího dějiště s místem, které současný čtenář zná nebo si může ověřit. ${ }^{13}$ To je jeden $\mathrm{z}$ oblíbených způsobů zahájení vyprávění, který dovoluje popsat jak aktuální situaci, tak poukázat k některým zvyklostem zobrazené doby. Často mu však ještě předchází explikativní úvod psaný v modu historiografickém, který děj předem zasazuje do širších dějinných souvislostí (Chocholoušek jej předesílá například románu Templáři v Čechách, 1843, nebo Cola di Rienzi, 1856). Takový rámec vyprávění je respektován jako zdroj poučení čtenáře a současně stvrzuje fakticitu klíčových událostí, resp. alespoň té množiny fakt, jež se obvykle označuje jako „historické jádro“ příběhu. Spolu s citacemi pramenů a odkazy k dějepiseckým autoritám potvrzují vypravěčovo věděni ${ }^{14}$ a posilují tedy i jeho autoritu, která se tu manifestuje, jak by

12) Ženské postavy jsou odvozeny od žánrových schémat: hraběnka z Vrtby patří k typu nemilosrdné intrikánky, její dcera k typu trpné slabé dívky; srovnat můžeme např́ílad se Sabinovým románem Ruesswurm (1866), kde ženy patří převážně k prvnímu typu (markýza, její služebná, Regina), druhý typ zastupuje milá řemeslníka Václava.

13) „Na Novém městě Pražském, v ulici nyní ,Uršulinská zvané, stojí tlupa lidu před domem velice výstavným, mohlt by se byl nazývati nádherným, kdyby všechen jeho zevnějšek největší spoustu, jak patrně vidno, byl nejevil“ (CHOCHOLOUŠEK 1900: 2-3, zvýr. AJ). Vidíme, že v jediném souvětí, jehož primárním úkolem dosáhnout názornosti a přibližení scény čtenáři, se nám scházejí ne méně než čtyři časové roviny: čtenářova a autorova současnost obecně (kurz.), „epické plusquamperfektum“ (podtrženě), „tady a ted““ vlastního děje (tučně), a splynutí času vypravěče a čtenáře $\mathrm{v}$ „názoru situace“ (tučná kurz.).

14) Magdalena Pokorná (viz 2001: 108) vysvětluje, že faktografie je v Chocholouškových prózách většinou správná, otázkou je, jak s ní naloží ve fabulaci. Pro příklad uved'me román Templár̆i (1843): v hodnocení panovníků se autor 
řekl již citovaný kolega, postojem historika promítnutým do diskurzu rétorického vypravěče.

Naučné vstupy v historizujících prózách mají leckdy charakter kulturněhistorický nebo historickogeografický, jako je tomu v druhé kapitole Hradu, kde jsou údaje navíc prostředkovány rétorikou vedoucí $\mathrm{k}$ nadsazené charakteristice (1) lokality:

„Městečko Votice v kraji Táborském velmi často připomíná se v dějinách českých. Mezi Prahou a Táborem, a to osm mil od Prahy, čtyry míle od krajského města Tábora jsou vzdáleno, má polohu hornatou, hory sestupují s dvou stran od východu a od západu tak blízko k sobě, že jen tolik místa mezi sebou ponechaly, co by se městečko Votice, potůček pode městem tekoucí a silnice Linecko-Pražská směstnaly. Silnice ta je velmi živá, a již od dávna spojovala jihovýchodní Čechy a Rakousy s hlavním městem Čech, s Prahou" (CHOCHOLOUŠEK 1900: 12).

Dalším odstavcem se začíná vlastní děj zobrazením již zmiňovaných jezdců na této cestě. Ta ale sama o sobě nemá s dalším jednáním postav co do činění. Následnost narativního zaostření od prostředí k postavám je sice zachována, ale motivace jejich nastolení je tu vlastně obrácená: uvedení postav na scénu se stává příležitostí k poskytnutí vedlejší historickogeografické informace. Naučné vsuvky mají v historizující próze své místo a můžeme v nich spatřovat nejen manifestaci naučné funkce díla, ale i přetrvávání oné starší „poetiky práce s nůžkami“, abychom parafrázovali Malurovu metaforu.

Proč se tedy vůbec pozastavujeme nad její nízkou vazbou k ději? V dobovém žánrovém poli totiž nacházíme v díle Chocholouškovy vrstevnice Boženy Němcové epicky efektivní alternativu práce s „kulturní historií“, a to ve vyprávění příběhu situovaného do nedávné minulosti a $s$ tématem $v$ zásadě moderním: totiž migrací obyvatel venkova do velkých měst. V krátké expozici povídky Dobrý člověk (1858) se také mluví o silnici, a sice o Vídeňské, po níž „[p]řed dvaceti lety, když ještě železnic v Čechách nebylo“ (NĚMCOVÁ 1972: 147), převážely těžké nákladní povozy zboží. Mezi povozníky vypravěč situuje také mužského protagonistu Hájka, kterého čtenář brzy identifikuje jako onoho „dobrého člověka“ avizovaného titulem povídky. Vypravěč vzápětí osvětlí důvody Hájkovy obecné oblíbenosti (velkorysost, spolehlivost, dobrota) a pokračováním v kulturněhistorickém výkladu o mladých či dokonce ještě dětských pasažérech mířících

shoduje s Palackým, zavádí do příběhu historickou postavu templářského velmistra Eka; vlastní děj se konstelací postav i některých jejich vztahů jeví jako echo Scottova Ivanhoea, velkou roli v něm hrají tajemství, neznámý či zamlčený původ, postava téměř magická apod. 
do vídeňské služby ${ }^{15}$ si připravuje půdu pro následující příběh. Od počátku je tak zřejmé, proč se setkání „dobrého člověka“ Hájka s dívčí protagonistkou Madlou (prchající do Vídně před nechtěným ženichem a zároveň rozhodnuté nalézt tam mladšího bratra, s nímž ztratila kontakt) vưbec mohlo odehrát: je vlastně možnou konkretizací mnoha nevyprávěných příběhů českých učedníků a služek v hlavním městě monarchie. Nejde tedy (jen) o kulturněhistorickou vsuvku pro nepoučeného čtenáře, nýbrž o zásadní charakteristiku světa příběhu, ontologickou podmínku rozvinutí děje.

Další podobou naučnosti historizujících vyprávění je zobrazení dobových zvyklostí, toho, jak „to tehdy chodívalo“, jak se lidé z různých vrstev typicky chovali, rozhodovali apod.; to může mít charakter vsuvky, spoluutvářet atmosféru nebo tvořit pozadí jednání postav. V Hradu jsou to třeba dobově přínnačné projevy dvornosti pánů v jednání s výmluvnou hraběnkou: úzus se pak dostává do kontrastu s napětím ve vzájemných vztazích.

Odkazy $\mathrm{k}$ autoritám, kulturněhistorické vsuvky i strategie zdůvěrnění světa příběhu poukazem $\mathrm{k}$ současnému stavu jeho dějiště jsou z hlediska epické výstavby vyprávění dvojsečné: upevňují autoritu vypravěče (stvrzují jeho znalost dobových poměrů a fakticitu událostí), nastolují komunikaci se čtenářem a poskytují př́ležitost $\mathrm{k}$ jeho explicitnímu zaangažování. Zároveň je však můžeme označit za prostředky „epicky zcizující“, nebot' se jimi zvýrazňuje epická distance. Kolísání vyprávění mezi zprávou o jedinečných událostech a výkladem dějin ovšem zpơsobuje, že čas narativního diskurzu se odtrhuje od času př́iběhu. Beneš Třebízský toto odtržení s oblibou rétoricky překlenuje tím, že ho explicitně tematizuje jako vypravěčovu vizi (srov. BROŽOVÁ 1999: 54-55). Jako by minulost zůstávala zakonzervována někde $v$ hlubinách časoprostoru a dovolovala, aby do ní povolaný (vypravěč nadaný zřením) nahlédl právě v okamžiku, který chce „postavit před oči“ svému čtenáři, nebo dokonce sama přicházela za ním. (V náznaku tento postup vidíme i v Chocholouškově úvodním obrazu drancování v expozici Hradu: na scénu hledí vypravěč společně se zaangažovaným čtenářem.)

Příběh Kaplír̆ů je místy i napínavý, a to nejen v konfliktu s katolíky, ale i v etických sporech protagonistů, jež Oldřich nakonec dokáže přesvědčit argumentací, že o cti více než pomsta vypovídá důstojnost a milosrdenství. V závěru (pátá

15) „Náklad, který Hájka skoro žádnou cestu neminul, byli malí chudí chlapci a děvčata, jichž rodiče do Vídně posílali, aby si tam našli učení nebo službu. Bylyt to děti nejvíce chudších obyvatelů z okolí Náchoda, Nového Města, Dobrušky, Opočna, také výše z dědin od kladského pohoří. Bylit' to obyčejně chlapci od desíti do třinácti let a děvčata od patnácti do dvaceti; málokterý z nich byl jaktěživ dvě hodiny za domácí humna přišel, málokterý znal číst, neřku-li psát" (NĚMCOVÁ 1972: 148). 
a šestá kapitola druhého dílu prózy) absorpce historiografického psaní vrcholí v zásadě mechanickou citací zprávy císařského generála Hatzfelda o průběhu bitvy u Jankova v březnu 1845 proti švédskému vojevi̊dci Torstensonovi. Vypravěč nejprve nastoluje modus velkých dějin coby pozadí „vyprávění našeho“ (CHOCHOLOUŠEK 1900: 217) a pak osvětluje volbu pramene: „Nejlépe porozumíme nesnázím jeho (Hatzfeldovým, AJ), když jeho vlastní zprávu, podanou císaři Ferdinandu III. písemně, zde doslovně položíme“ (IBID.: 217-218). ${ }^{16}$ Poetika „nůžek“ je zřejmá i z toho, že vypravěč zprávu „stříhá“ na několik částí a utne třeba v půli věty, aby mohl poreferovat o situaci hrdinů příběhu. Poslední citaci uzavírá v interpretativně kronikářském tónu výsledku a následcích bitvy, celé vyprávění pak explicit v kronikářské dikci: „A to bylo posledně, co o Kaplířích ze Sulevic v dějinách českých děje se zmínka“ (IBID.: 261).

Do reprodukce Hatzfeldova podání bitvy jsou protagonisté př́iběhu vloženi asi tak, jako bychom jejich papírové figury vlepili do popředí panoramatické rytiny; popřípadě napojeni dodatečně. Do popředí se tak dočasně nasouvá i postava Zdeňka Kaplíre, který nachází svého saského přítele z Amstettů v krvi a dojemně se $s$ ním loučí. Taková scéna rozhodně má místo $v$ příběhu soustředěném $\mathrm{k}$ válečné zkušenosti, $\mathrm{v}$ daném kontextu je zase spíše „obrazem“, ba ilustrací. - Alternativa, kterou tu pro srovnání „epické efektivity“ můžeme postavit, není ovšem paralelní jako v prvním případě, pochází z Jiráskovy téměř o patnáct let mladší povídky Turečkové (1876). Příběh je spíše než na kauzalitě událostí vystavěn na epizodickém prostřídání členů skupinky českých žoldnéřů (přesvědčených evangelíků i dobrodruhů) ze saského pluku nazývaného podle obávaného velitele. Závěrečná dojemná scéna loučení skupinky vojáků s umírajícím velitelem je zároveň jejím symbolickým rozpuštěním. Abychom nebyli nespravedliví, dodejme, že i toto vyprávění má naučně interpretativní závěr, přestože jako individuální ilustrace osudů třicetileté války je příběh dostatečně přesvědčivý; není divu, že v Jiráskově rané povídce pozorujeme uplatnění žánrové konvence. ${ }^{17}$

V průběhu zkoumání vyprávění 19. století připomínal již citovaný kolega Koten, že bychom se měli snažit oprostit od naratologických předsudků a sledovat, „co vyprávění opravdu dělá“. Je třeba přiznat, že u Chocholouška to vůbec není snadné: z pohledu narativní koherence se může zdát, že autor své vyprávění

16) Informace $z$ diskurzu historiografického jsou v poznámce pod čarou doplněny o informace folkloristické: původ rčení „Vyhráš jako Kec u Jankova“ (narážka na císařského polního maršálka z Götzu, kterého švédské vojsko zaskočilo v úzkém údolí) a citace lidové písně traktující poslední slova vojevůdce (CHOCHOLOUŠEK 1900: 248).

17) Podrobný rozbor viz JEDLIČKOVÁ 2020. 
„některé věci prostě dělat nenechá“: například přesvědčit čtenáře rozložením sil v příběhu, tedy „zevnitř“. Má potřebu přesvědčovat jej „zvenčí či „shora“, zdůraznit autenticitu zpráv i poučení plynoucí z rámcových historických událostí a současně tak upevnit autoritu vypravěče, a sahá proto v poslední části Hradu k „nastavování“. To mění nejen dosavadní diskurz, ale také rozpětí světa př́iběhu, který se mohl opřít o spor, do nějž se promítá touha po moci, vyznání, rodová hrdost i zmařená láska, a nyní je rozšířen na úroveň „velkých dějin“, jež však proto nepřestávají být tím, čím byly dosud, totiž kulisami, pozadím příběhu. Fakt, že jako diskrepance se tento postup může jevit nejen v „retrospektivním“, ale i dobovém čtení, potvrzuje citace kritiky, již ve své monografii o Chocholouškovi registruje Magdalena Pokorná. Neruda v recenzi vydané v Obrazech života (1860) zaznamenává i klady Chocholouškovy práce, vytýká však právě ustrojení závěru: „Zakončení podobá se řece v písku mizící a nezbude leč dojem nepř́ijemný, jakýž každá chvatná práce zůstaviti musí" (cit. dle POKORNÁ 2001: 138-139). Chocholouškova žurnalistická praxe a psaní pod tlakem pro pracně získané subskribenty větších próz napovídá možné příčiny onoho chvatu; ale pouhá spekulace bez průzkumu konkrétních okolností psaní a publikace (je-li možný) náš náhled nezostří. Spíše se to jeví tak, že Chocholoušek spolehl na absorpci historiografického psaní a strategii „nůžek“, v rámci žánru dobově zcela přijatelnou. $V$ povrchové rovině však přiliš nedbal na textovou koherenci, ba kohezi (zakončování citací pramene v půli věty a zkratkou), ale ani na to, co bychom mohli nazvat epickým rozměrem dosavadního vyprávění. Novelistické intimizaci historického konfliktu do morálního a emocionálního střetu několika postav v relativně omezeném prostoru totiž v závěru nastolená rovina velkých dějin spíše konkuruje, než aby ho potencovala. Vlastní příběh potlačené pomsty a velkorysosti se totiž už odehrál, a smrt dvou postav následkem bojů na něm nic nezmění, ani jeho výsledky nepečetí. Dobová přijatelnost takového postupu (byt' s výhradami kritika) se tak zakládá na třech parametrech: přetrvávání poetiky „nůžek“ v žánru, jeho naučné funkci a étosu spojeném s tématem.

\section{Epizovaný dokument nebo zdokumentovaný př́iběh?}

Zkusme s dosavadními nálezy porovnat o málo mladší Sabinovu prózu Osudná kniha (1862, knižně až 2013), která s dobovými dokumenty pracuje soustavně. Expozice vyprávění je tu postavena na oblíbeném schématu: z rozmluvy 
postav v důvěrném prostředí (u rychtáře v Dobravicích) se dozvídáme i prehistorii příběhu, z aktuální diskuse o zápasu českých stavů i to, že místní pán Hynek z Valdštejna je pro měštany př́kladem neohroženého českého šlechtice. Tiskař Mizera (vyučený u Adama z Veleslavína) tu může prozradit, že pan Hynek nechává tisknout knihu s názory, jež Mizera nespecifikuje, ale hodnotí jako odvážné; opatrný rychtář se leká. Následující zápletka spočívá v tom, že tiskařova nevěrná žena Majdalena spolu se svou kamarádkou Zuzanou a milenci obou žen vymyslí plán na využití knihy k vlastnímu obohacení: Mizerův sazeč Hous vyrobí další výtisky navíc, ty pak podloudně prodají v Praze, a až přijdou k penězům, vydají se do světa. Kniha je však brzy zabavena a vystopována až k Hynkovi z Valdštejna. Ten veškerou vinu shodí na tiskaře Mizeru, a aby nepromluvil, dá jej potajmu popravit. Strůjci nevydařeného podniku utečou za hranice, Hynek z Valdštejna se vykoupí doslovně i konfesijně přihlášením ke katolíkům.

Také v tomto narativu jsou zpráva o jednání postav a vypravěčské komentáře ke světu příběhu, jinak řečeno fikční diskurz, ${ }^{18}$ propojeny s přejímáním informací z jiných diskurzů, resp. s citacemi dobových dokumentů. Sabina se tu neobrací jako často jeho předchůdci k dosavadnímu zpracování tématu dějepiseckými autoritami, nýbrž vychází z vlastního pramenného studia (k tomu srov. CHARYPAR 2014). Způsoby zapojení úryvků odjinud, tedy míra vyznačení mísení diskurzů (fikční, historický obchodní, právní) se tu různí, někdy se značení dokonce jeví jako redundantní, ale výsledkem je mnohem silnější „efekt“ narativní koherence než u Chocholouška. Zkusme odhalit faktory, které k tomu přispívají.

Prvním z nich by mohlo být zapojení obsahu faktuálních textů do výstavby děje. Sabina ovšem nastolí takovou situaci, aby krátký dokument mohl být doslovně citován: Majdalena smlouvu uzavřenou s Hynkem z Valdštejna ukradne svému muži (v posledku tím přispěje $\mathrm{k}$ jeho konci, protože tiskař nemůže doložit, že zadavatelem byl Hynek) a předkládá ji ostatním spiklencům. Sazeč Hous se totiž chce přesvědčit, zda v ní není jmenován, bojí se odpovědnosti. Smlouvy se chopí knihař Václav: „Oči všech pak ulpěly na něm, když čísti počal: ,Cedule řezaná JM pána pana Hynka z Valdštejna s Ondřejem Mizerou, o vytištění jistého počtu exemplářů knihy historické učiněná“" (SABINA 2013: 232). Scéna je jako taková velmi přesvědčivá, Sabina však v souladu s dobovou konvencí pramen nejen přesně ocitoval, ale také ověřil jeho autenticitu v poznámce. ${ }^{19}$

18) Řešíme ovšem pouze úroveň diskurzu; otázka, zda postavy příběhu mají své jednoznačné historické protějšky, nebo jsou fiktivní, není pro naši úvahu podstatná (k tomu tématu srov. CHARYPAR 2014: 100nn).

19) Editoři současného pečlivě připraveného a komentovaného vydání (2013) P. Hesová, V. Vaněk ji stejně jako pozdější odkaz na autenticitu dopisu Hynka z Valdštejna vyňali, z hlediska čtenářského. 
Jindy je zdroj zcela jednoduše označen v samotném textu a využity jsou i zcela nespecifické informace, které mohly být zapracovány do vyprávění: „Ze zprávy Mikuláše Zajíčka. Poslali pro mne a já hned bez meškání jsem se dostavil“ (IBID.: 270). Oba diskurzy, resp. zdrojový a přijímající text zůstávají zřetelně vyznačeny, v prvním vydání autor na některým místech zdůraznil autenticitu pramene poznámkou. Přesto textové uspořádání Osudné knihy, jež také vzniklo za pomoci „nůžek“, působí uceleněji než u Chocholouška: různé pramenné složky přinášejí totiž informace relevantní pro vývoj událostí na té úrovni, s níž čtenáře seznámilo vyprávění příběhu a vztahují se přímo $\mathrm{k}$ jednajícím postavám. (Původci těchto textů jsou ostatně nejčastěji historické protějšky fikčních postav.) Rovina vyprávění individuálního příběhu a zdokumentovaných dějin zůstávají v tomto smyslu (a zvláště ve srovnání s příkladem z Chocholouška) vzájemně vyvážené.

Dalším zdrojem narativní koherence je vyprávěcí styl, jehož efekt nedovedu vypsat než jako paradoxní: přestože výrazově může být velmi intenzivní, až expresivní, nepůsobí nijak rozníceně, naopak. I ty pasáže, které zobrazují napjatou situaci - jako vstupní scéna s překvapivou informací, konspirační schůzka podvodníků, návrat tiskaře Sixta Palmy pronásledovaného za protivládní psaní, jemuž Mizera ze strachu před ženou odmítne přístřeší a ubožák venku zmrzne, nebo poslední chvíle vězněného Mizery - jsou zprostředkovány dosti střízlivou dikcí, řekli bychom jakýmsi „uvážlivým“ podáním. To se pak stylově nedostává do výrazného kontrastu s „uvážlivostí“ dobových dokumentů. Vypravěčovy komentáře ke světu příběhu, ale i dokumentům dokládajícím jeho historickou podobu, mají rozpětí od věcného konstatování až po odsudek. Pohled na manželství tiskaře Mizery s moci- a majetkuchtivou Majdalenou, jež navenek své nároky tlumí, vede k zobecnění životních pravidel:

„Bedlivý pozorovatel by byl snadno souditi mohl, že se stř́izlivý, poněkud váhavý a chladný Ondřej nehodí k ženě této. Něco takového však nikomu v Dobravicích nenapadlo. Manželství jest jistému druhu lidí pouze stavem vzájemných povinností, jejichž kruh se za vyplněný považuje, když se aspoň vưčihledě nepřekročí“ (IBID.: 231-232).

Naopak hodnocení spisu, který si Hynek z Valdštejna objednal na svou obhajobu, je silně zaujaté:

„Plod této smlouvy uveřejněn byl roku 1618 v měsíci máji pod názvem Jana Pravdy Litovanského Apologie aneb Vypsání velikého a těžkého neštěstí, v které pán z Valdštejna původem zlých lidí 
uveden byl. Spis tento hnusí se nejapnou sofistikou, odporováním sobě na mnohých místech a úplným překrucováním pravdy“ (IBID.: 273).

Jako čtenářka přiznávám, že při prvním čtení se mi hranice diskurzů místy rozplývaly.

Mohli bychom říci, že efekt koherence tu výrazně podporuje textová koheze, text splňuje stylistický nárok na to, aby byl „výrazově spojitý“ (srov. ČECHOVÁ et al. 2008: 121). To sice neznamená, že by tu nedocházelo k projevům toho, co bychom mohli nazvat jistou hodnotovou inkonzistencí v narativním diskurzu: Vypravěč tu vedle rekapitulací dobových postojů formuluje také retrospektivní hodnocení zjevně plynoucí z aktuálních společenských hodnot v čase vzniku vyprávění: Hynkovo přijetí jiného vyznání vnímá jako paralelu současného „přeběhlictvi“" politického; naopak pro předpokládaného ${ }^{20}$ autora „osudné knihy“ Magerleho ze Sobíšku má slova uznání, jež důrazem na „moderni“ hodnoty opět prozrazují retrospektivní pohled. Ale prozrazují také to, že tato stanoviska jsou výsledkem jedinečného průzkumu a interpretace dobových dokumentů, nikoli převzetím autorit:

\begin{abstract}
„Muž tento, nadobyčejně učený a výborný právník, v dějinách země obzvláště zběhlý, vládl pérem velmi ostrým. Ze všech svědectví, jichž o něm dopíditi se lze, vysvitá patrně, že náležel do řady oněch vzácných charakterů českých v pohyblivé oné době, jež náboženské horlivosti národu i stavů českých použivati mínily ku provedení svobodných zásad politických. Neleželt' mu protestantismus tak na srdci jako ústava zemská a volný, co možná nejširší rozvoj její ku všeobecné občanské svobodě (SABINA 2013: 252, zvýr. AJ).
\end{abstract}

Aktualizační akcenty patři k typickým projevům prózy historizující, tj. často využívající historických či minulosti připsaných událostí a okolností jako základu pro fabulaci umožňující traktování takového příběhu, jaký může čtenáře oslovit problémy paralelními s těmi současnými, zvláště vlasteneckými. Vypravěčské komentáře tu však nejsou natolik silné ani extenzivní, aby působily proti historicitě příběhu.

Možná by ostatně bylo vhodnější mluvit o „rekonstrukci kauzy“, jako to činí Michal Charypar v citované studii (2014: 95); z hlediska způsobu nakládání s dobovými dokumenty, respektive jeho žánrově a diskurzivně pomezního přístupu pak označuje Sabinu za předchůdce Winterova. Dovolím si jít ještě dále

20) Nedochovaný spis je přisuzován Václavovi Magerlemu ze Sobíšku; podrobněji k námětu a Sabinovu průzkumu pramenů srov. CHARYPAR 2014, zvl. 95-101, souhrnně k Sabinově psaní o minulosti VANĚK 2013, 335-344. 
a doložit ukázkou, že tu nacházíme, byt' v několika málo kratších výskytech, i postup předjímající žánr detektivní. Jde o zobrazení úvah a hypotéz dvou úředníků pověřených vyšetřením původu „osudné knihy“. Konšel Tykva, který Majdalenu i Mizeru dobře znal, ale činil si o jejich vztahu úsudek na základě představy o manželství, již jsme výše citovali, dospívá k tomu, že přehodnocení tohoto postoje možná přináší motivaci Majdalenina jednání. Také úředník Mikuláš Zajíček se z indicií a dosavadních útržkovitých poznatků také snaží „sestavit příběh“, vyvozuje otázky po motivacích jednání postav, jež by událostem dodaly logiku:

„Počal přemítati a hle, živá stopa před ním ležela. Kdo byl první na místě u zmrzlého, kde Sochor smlouvu našel? Kterak knihař přišel k listině, o níž Mizera tvrdil, že ji dobře uschovanou měl a nikomu neukázal? Nebylo-li nejvíce pravděpodobné, že Majdalena ji za nějakou př́činou odcizila a knihaři dala? Ale jaká toho mohla býti prýčina? Na této otázce uvázly další důmínky, a i ty vzniklé se jevily bez podstaty.

Nicméně přece se Zajíček nevzdal předsevzetí, že v té věci dle možnosti světla nabude“ (SABINA 2013: 273).

Zatímco dějepisné psaní nás chce zpravit o tom, „jak to bylo“, Sabina vnáší do svého vyprávění epistemické gesto, jež bychom mohli vyjádřit přeformulováním „jak to mohlo být? jak se to vlastně seběhlo?“. I v dalších Sabinových prózách, at' už s historickým, nebo současným námětem (Ruesswurm, 1866, Oživené hroby 1870) najdeme spekulace postav, v prvním případě spojené s intrikánskými sklony protagonistů, v druhém s jejich situací ve vězení: útržkovité a nejisté zprávy vedou často $\mathrm{k}$ nadsazeným hypotézám. Jsme tu však svědky narativního gesta, jímž Sabina překračuje dosavadní žánrový práh a které bychom mohli označit jako epistemické. Oproti příležitostnému dovolávání se autorit či relativně mechanické citaci pramenů je Sabinův narativ postaven kolem postavami sceleného výběru historických pramenů a jejich vypravěčskou (důslednou badatelskou prací autora podloženou) interpretací. Jde skutečně o narativní re-konstrukci kauzy za absence klíčového předmětu doličného, „osudné knihy“. Jako scelující síla tu působí trochu paradoxní dějový protipohyb: Zajíčkovo pátrání je postupem proti času událostí, které čtenář už zná; zároveň je ale stvrzováním logiky událostí a vztahů, a tedy pohybem vpřed v čase příběhu.

Zdrojem koherence vyprávění je v Sabinově případě ovládnutí kombinace diskurzů a žánrů, přestože jejich sklad v textu zůstává nadále formálně přiznaný, není-li přímo zvýrazněn. Podstatou této vypravěčské kontroly je podřízení 
volby dokumentů potřebám logiky událostí, kterou zasvěcenému čtenáři zvýrazní proces dobového vyšetřování.

Z uvedených příkladů historizujících próz je zřejmé, že narativní koherence není nějakou univerzální kvalitou, jíž by tento žánr ve své době měl dosáhnout: proti textové koherenci se staví potřeba využít všech reprezentačních (1) možností nastolení názorných a působivých obrazů dávných časů; proti kohezi vypravěčské dikce zase potřeba upevňování vypravěčské autority (postoj historika) a autentifikace událostí. Historizující prózu první poloviny až šedesátých let 19. století lze tedy do jisté míry podložit matricí staršího, diskurzivně ještě zásadně nerozlišeného psaní o dějinách, jež nejen připouští, ale přímo předpokládá kompilaci. Označení prózy za historizující se opírá právě o fakt, že na tuto matrici je přiložena fólie jedinečného př́běhu. Sabinova próza Osudná kniha se vymyká tím, jak její autor dovede propojit jazyk obou už zřetelných diskurzů (fikčního narativu a dobových právních ad. dokumentů), ale také tím, že pokus o ustavení koherence př́běhu inscenuje ve formě vyšetřování $v$ jeho vlastním světě.

$\mathrm{Na}$ „zprocesování“ historických dokumentů do epického podání vyvažujícího mezi zájmem o události a postavy a mezi soukromým a společenským jednáním, čekají čeští čtenáři 19. století až do přelomu let sedmdesátých a osmdesátých. Teprve Jiráskovy první románové prózy se vyznačují koherencí, jež jednou - snad - může být předmětem onoho modernistického rozrušování.

Přispěvek vznikl v rámci grantu GA ČR 18-04420S, Proměny narativních způsobů $v$ české próze I. Při práci na publikaci byly využity zdroje výzkumné infrastruktury Česká literární bibliografie (http://clb.ucl.cas.cz), (kód ORJ: 90136).

\section{PRAMENY}

CHOCHOLOUŠEK, Prokop

1900 (1860) Hrad. Dějepisná pověst z třicetileté války (Praha: Bursík a Kohout)

NĚMCOVÁ, Božena

1972 (1858) „Dobrý člověk“, in táž. Karla, Divá Bára, Chudí lidé, Dobrý člověk, Pan učitel, ed. Zdeňka Havránková (Praha: Státní pedagogické nakladatelství), s. 147-222

ROKOS, František Alexandr

2005 (1824) „Zasnoubení na bojišti“, in KUSÁKOVÁ, Lenka (ed.). Zábavné povídky raného obrození (Praha: Nakladatelství Lidové noviny), s. 24-54 
SABINA, Karel

2013 (1862) „Osudná kniha“, in týž. Osudná kniha. Tři prózy z doby reformace. Ed. Petra Hesová a Václav Vaněk (Praha: FF UK), s. 225-276

\section{LITERATURA}

BREMOND, Henri 2002 (1966) „Logika narativních možností“, in KYLOUŠEK, Petr (ed.). Znak, struktura, vyprávění. Výbor prací z francouzského strukturalismu (Brno: Host), s. 118-141

BROŽOVÁ, Věra

1999 „K tvưrčí osobnosti Václava Beneše Třebízského. Historický pramen, fikce a mýtus“, Posel z Budče č. 16, s. 52-55

ČECHOVÁ, Marie - KRČMOVÁ, Marie - MINÁŘOVÁ, Eva 2008 Současná stylistika (Praha: Nakladatelství Lidové noviny)

HESOVÁ, Petra

2013 „Sabinovo vypravěčství a jeho zdroje“, in SABINA, Karel. Osudná kniha. Tři prózy z doby reformace (Praha: UK - FF), s. 345-355

\section{CHARYPAR, Michal} 2014 „Česká historizující próza mezi romantismem a realismem. Rekonstrukce historické právní kauzy Henyka z Valdštejna v povídce Karla Sabiny Osudná kniha“, Bohemica Litteraria 17, č. 1, s. 87-105

\section{CHATMAN, Seymour}

2008 (1978) Příběh a diskurs. Narativní struktura v literatuře a filmu (Brno: Host)

JEDLIČKOVÁ, Alice

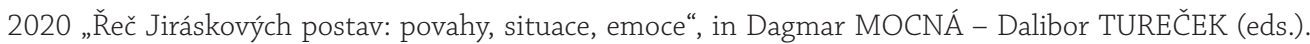
Tradicí stvořená. Jaroslavě Janáčkové k devadesátinám (Praha: ÚČL AV ČR), s. 116-128

MALURA, Jan

2021 „Očividná minulost. Reprezentace prostoru v bohemikálních dějepisných textech 16. a 17. století“, Česká literatura, č. 2, s. 155-196

PIORECKÁ, Kateřina 2020 „K temporalnosti naracije u češkoj povijesnoj prozi 19. stoljeća. Model dramskog dijaloga. Književna smotra: Časopis za svjetsku književnost 52, č. 198 (4), s. 25-35

POKORNÁ, Magdalena 2001 Milován a sledován. Český spisovatel Prokop Chocholoušek 1819-1864 (Praha: Práh/Archiv AV ČR)

2021 Objevení dějin. Dějepisectví, fikce a historický čas na prèlomu 18. a 19. století (Praha: Academia) 
Alice Jedličková

Narativní koherence jako průvodní rys proměn žánru

TOOLAN, Michael

2013 (2011) „Coherence“, in Living Handbook of Narratology, http://www.lhn.uni-hamburg.de/node/69. html; <př́stup 20. 9. 2021>

VANĚK, Václav

2013 „Historická beletrie jako repetitorium národních dějin“, in SABINA, Karel. Osudná kniha. Tři prózy z doby reformace (Praha: UK - FF), s. 335-344

Doc. PhDr. Alice Jedličková, CSc., jedlickova@ucl.cas.cz; Oddělení teorie, Ústav pro českou literaturu AV ČR, v. v. i., Praha, Česká republika/ Theory department, Institute of Czech Literature of the CAS, Prague, Czech Republic 